Małgorzata Laskowska

\title{
Lęk psalmisty przed nieprzyjacielem
}

Motyw nieprzyjaciela obecny jest w całej Biblii. Już w Księdze Rodzaju zauważa się nienawiść, i to w środowisku, w którym nie powinna ona mieć miejsca, a mianowicie w rodzinie (Kain-Abel - Rdz 4, 1-16; Sara-Agar - Rdz 16, 1-7; Jakub-Ezaw - Rdz 27-29; Józef-bracia - Rdz 37, 4; AnnaPeninna - 1 Sm 1, 6n).

Wszelkie prośby, lamenty, złorzeczenia zawarte w psalmach są wynikiem konfliktu z nieprzyjacielem. Przykłady te pozwalają zauważyć lęk przed drugim człowiekiem. W przypadku psalmisty jest on prosty i konkretny. Nie lęka się on, jak jest to współcześnie, relacji z drugim człowiekiem, codziennego z nim obcowania. Niepokój czy nawet trwogę mógł wzbudzić w nim jedynie człowiek prawdziwie wrogo do niego lub do Boga nastawiony.

„Nieprzyjaciel” w Starym Testamencie określony jest terminem 'ōjēb, który wyraża „fakt antagonizmu”" Pojęcie to odnosi się jednak wyłącznie do wroga Izraela, przeciwnika z zewnątrz. Nigdy nie jest ono używane w odniesieniu do samego Izraela².

Innym starotestamentowym pojęciem dotyczącym zjawiska nieprzyjaźni (nieprzyjaciela) jest słowo „ciemięzca” wyrażane terminem șar oraz „nienawistnik" - śōnē’3.

\section{Określenie typów nieprzyjaciół w psalmach}

Analiza wspomnianych we wstępie biblijnych przykładów nieprzyjaźni ukazuje jej przyczynę. Jest to niewątpliwie zazdrość, pożądliwość, żądza posiadania rzeczy, przywileju czy względów. Ustalenie powodów wrogości pozwala wyróżnić typy nieprzyjaciół.

${ }^{1}$ Por. J. Schreiner, R. KAmpling, Bliźni-obcy-nieprzyjaciel z perspektywy Starego i Nowego Testamentu, tł. J. Zychowicz, Kraków 2001, s. 55.

${ }^{2}$ Por. J. Schreiner, R. KAmpling, Bliźni-obcy-nieprzyjaciel..., dz. cyt., s. 56; H. RingGREN, 'ājab, [w:] Theologisches Wörterbuch zum Alten Testament, hrsg. von G. J. Botterweck, H. Ringgren, t. 1, Stuttgart-Berlin-Köln 1973, 228-235, 231.

${ }^{3}$ Por. J. Schreiner, R. Kampling, Bliźni-obcy-nieprzyjaciel..., dz. cyt., s. 55. 
Do pierwszej grupy zalicza się przyjaciół i krewnych. Na skutek choroby odwrócili się oni od bliskiej osoby (por. Ps 37, 12; J 9, 2). Wszelkie schorzenia i dolegliwości zdrowotne według starotestamentowej mentalności rozumiane były jako ukaranie za złe postępowanie. Cierpienie i stan chorobowy sprawiły, że człowiek nie sprostał wymogom przyjaźni. Nie tylko odchodzi, ale robi niemiłe uwagi względem chorego. Oczernia go i potępia.

Do drugiej grupy bibliści zaliczają bezbożnych i bluźnierców, którzy żywią nienawiść z powodu cnotliwości człowieka (por. Ps 68, 11-13). W rzeczywistości sprzeciwiają się oni Bogu i Jego opatrzności. Często są to dawni nieprzyjaciele wykorzystujący bezradność chorego. Słuszność swoich sądów uzasadniają, mówiąc: „Jahwe ich ukarał” (por. Ps 30, 12-14; $34,15 \mathrm{n} ; 68,27 ; 108,22-25)^{4}$.

W psalmach spotykane są również inne przypadki lęku przed człowiekiem. Może on zrodzić się w przypadku, kiedy wiara psalmisty jest powodem do śmiechu i prześladowania (Ps 3, 3). Ten poszkodowany zwyczajnie obawia się zawstydzenia przed wrogiem ('al-'ébôš $\bar{a}(h)$ ) w momencie, gdy nie zostanie wystuchany (por. Ps 25,$3 ; 31,18)^{5}$. Wrogowie mieliby wtedy szczególny powód do śmiechu, bo ten zaufał daremnie.

Nieprzyjaciel często określany jest jako zōr („,obcy”) lub zēed („zuchwały”). „Na taką lekcję wskazuje paralela 'ārîșîm, która oznacza ludzi gwałtownych, nie mają oni skrupułów, aby siłą przeprowadzić swoje plany. [...] Tak określeni wrogowie powstają przeciw psalmiście i usiłują pozbawić go życia”.

Psalmista zalicza tych wrogów do obcych (por. Ps 54, 5). Mogli to być też Izraelici, którzy sami umieszczali się poza ludem przymierza (por. Iz 1, 4).

Wszelkie uczucia nienawiści ze strony ludzi wprawiają go w wielkie udręczenie i obciążenie psychiczne (por. Ps 25, 15-18). Został bowiem niewinnie oskarżony o coś, czego do końca nie rozumie. Ci wrogowie działają w thumie, co potęguje strach prześladowanego. Szuka często schronienia w świątyni, gdzie składa przysięgę o swojej niewinności (por. Ps 26; 71; $1 \mathrm{Krl} 8,31 \mathrm{nn}$ ).

\section{Rodzaje lęków przed nieprzyjacielem}

Lektura omawianych fragmentów Księgi Psalmów pozwala wyszczególnić typy lęku. To m.in. obawy i niepokoje króla. W przypadku monarchy jest to strach przed wrogiem militarnym, politycznym najeźdźcą. Lęk towarzyszący królowi wydaje się posiadać poważne uzasadnienie. Chodzi tu najczęściej

\footnotetext{
${ }^{4}$ Por. W. Harrington, Klucz do Biblii, tł. J. Marzęcki, Warszawa 1982, s. 265.

${ }^{5}$ S. Łach, Księga Psalmów. Wstęp - przekład - komentarz-eksursy, Poznań 1990, s. 187.

${ }^{6}$ Por. tamże, s. 283.

${ }^{7}$ Tamże, s. 283.
} 
o spory dotyczące posiadania ziemi, terenów, plonów, „o ucisk ludności, która jest poddawana zależności od obcych władców i używana przez nich do własnych celów". Zauważa się tu pewne kryterium, na podstawie którego można dany kraj zaliczyć do wrogiego. Chodzi tu o stosunek narodu do zamysłu Jahwe względem Izraela. Bóg bowiem wybrał sobie naród, obdarzył go krainą i prawem. W momencie, kiedy obcy lud narusza ten porządek, chcąc dokonać zmiany korzystnej dla siebie, staje się wrogiem Izraela9

„Terminy «lęk» i «bojaźń» pochodzą zapewne z języka wojennego. Przed wyruszeniem na wojnę król pytał wyrocznię. W swej odpowiedzi zapowiadała oddanie wrogów w jego ręce, przy czym przychylne bóstwo osobiście miało brać udział w działaniach wojennych, wywołując u wrogów «strach», «lęk»" Chodzi tu o rzadko spotykaną w Biblii syntezę lęku i bojaźni jednocześnie.

W Ps 20, 2 król w dniu utrapienia (bejôm șārā $(h)$ ) odczuwa trwogę przed obcym najeźdźcą. Psalmista jego lęk uzasadnia oblężeniem Jeruzalem (za Ezechiasza-2 $\mathrm{Krl} 18)^{11}$. W obliczu tego lęku, nie tylko monarcha prosi Boga o błogosławieństwo: „Jak długo, Panie, całkiem o mnie nie będziesz pamiętał? Dokąd kryć będziesz przede mną oblicze? Dokąd w mej duszy będę przeżywał wahania, a w moim sercu codzienną zgryzotę? Jak długo mój wróg nade mnie będzie się wynosił?” (Ps 13, 2-3) ${ }^{12}$, ale i cały naród: „Niech Pan cię wysłucha w dniu utrapienia, niech ciebie chroni imię Boga Jakuba. Niech ześle tobie pomoc z świątyni i niech cię wspiera z Syjonu. Niechaj pamięta o wszystkich twych ofiarach i niech Mu będzie miłe twe całopalenie. Niech ci udzieli, czego w sercu pragniesz, i wypełni każdy twój zamysł” (Ps 20, 2-5) ${ }^{13}$.

Modlitwy tego rodzaju poprzedzały zawsze wyprawę wojenną. Uczucie lęku przeniknięte jest też proroczą pewnością o pomyślnej interwencji ze strony Boga podczas niebezpieczeństwa: „Teraz wiem, że Pan wybawia swego pomazańca, odpowiada mu ze świętych swych niebios, przez możne czyny zbawczej swej prawicy" (Ps 20,7).

W psalmach ciągle pojawia się synteza skargi, prośby i pełnego zaufania czy lęku i spokoju. Podobna zależność pojawia się w przypadku analizowania lęku króla. W Ps 27 zauważa się prawdziwy spokój wodza przed

${ }^{8}$ J. Schreiner, R. Kampling, Bliźni-obcy-nieprzyjaciel..., dz. cyt., s. 55.

${ }^{9}$ Por. tamże, s. 56.

${ }^{10}$ J. Suchy, Ekologiczne przestanie Biblii, [w:] Życie społeczne w Biblii, red. G. Witaszek, Lublin 1997, s. 183.

${ }^{11}$ Por. S. ŁaCh, Księga Psalmów..., dz. cyt., s. 167.

${ }^{12}$ Por. Ps 17 ; 18, 5- 7; 25; 31; 35; 39, 5-14; 54; 55; 56; 59; 64; 69; 70; 71; 83; 86; 88; 109; $129 ; 140$.

${ }^{13}$ Por. Ps 21; 48. 
spotkaniem się z wojskiem nieprzyjaciela ${ }^{14}$ : „Kogóż mam się lękać? [...] Przed kim mam się trwożyć?" (Ps 27, 1).

Z czego wynika jego zaufanie i opanowanie w działaniu? Król na podstawie obietnicy Boga (por. Iz 28, 16), że fundament państwa izraelskiego będzie na Syjonie, pokłada w Nim całkowitą ufność. Zdaje więc sobie sprawę, że od niego - człowieka (choć jest głową narodu) - nie zależy zwycięstwo. Nie sam Syjon przynosi wybawienie, ale oczywiście Ten, który tam mieszka ${ }^{15}$.

Według tradycji izraelskiej obecność Boża, a więc i Jego pomoc szczególnie objawia się rankiem (czwarta straż nocna) ${ }^{16}$. O takiej porze miał często miejsce atak wroga. Ps 46, 5-8 wyraźnie wskazuje na taką interwencję Boga, który przychodzi z pomocą podczas najazdu nieprzyjaciela na miasto. Dane historyczne umieszczają te wydarzenia przed niewolą, kiedy Jerozolima odparła atak wojsk Sannacheryba (por. 2 Krl 18, 1-19, 37) dzięki pomocy Boga. W zamian psalmista oddaje Mu cześć. W ww. 9-12 umieszczony jest zachwyt nad tym, jak Jahwe niszczy broń wroga, a więc eliminuje przyczynę lęku.

W psalmach zauważa się również lęk pielgrzyma przed poganami, bezbożnikami czy też przed złymi duchami. Szczególnie jest on zauważalny w psalmach o Syjonie (7) odśpiewywanych przez pątników zbliżających się do świętego miasta ${ }^{17}$ lub też w tzw. psalmach pielgrzymkowych (Ps 84 i tzw. psalmy wstępowań 120-134) ${ }^{18}$. Uczucie strachu towarzyszy też psalmiście w utworach o charakterze liturgicznym (Ps 24; 29; 48; 65; 92; 95; 96; 102, 118; 134; 135 itd.).

W Ps 102 pielgrzym przybyły do świątyni wylewa przed obliczem Boga swoje skargi. Opowiada o przyczynach swojego lęku. Czuje się samotny: „Czuwam i jestem jak ptak samotny na dachu” (Ps 102, 8). Prześladują go obcy i wrogowie, którzy życzą mu źle, przeklinają, zniesławiając jego imię: „Każdego dnia znieważają mnie moi wrogowie, srożąc się na mnie przeklinają moim imieniem" (Ps 102, 9).

Psalmista swoich osobistych wrogów utożsamia zdecydowanie z wrogami Boga. On jak gorliwy czciciel Jahwe bulwersuje się niegodziwym postępowaniem (Ps 37, 1-6). „Zło uważa jednak za coś realnego i nie traktuje wroga jako osobę dorosłą. Uważa wroga za istotę duchową, o której

${ }^{14}$ Por. S. Łach, Księga Psalmów..., dz. cyt., s. 193.

${ }^{15}$ Por. W. Borowski, Psalmy. Komentarz biblijno-ascetyczny, Kraków 1983, s. 93.

${ }^{16}$ Por. S. Łach, Księga Psalmów..., dz. cyt., s. 255.

${ }^{17}$ Jerozolima stała się stolicą Izraela za panowania króla Dawida w XI w. p.n.e. Została tu przeniesiona przez króla Arka Przymierza z tablicami dziesięciorga przykazań, co nadało miastu kultyczno-religijny charakter. Jedno ze wzgórz Jerozolimy to Syjon, na którym to następca Dawida król Salomon wzniósł świątynię.

${ }^{18}$ Por. J. Synowiec, Wprowadzenie do Księgi Psalmów, Kraków 1996, s. 60. 
Bóg wie i przeciwko której występuje"19. Z tego też względu zwraca się o pomoc bezpośrednio do samego Boga. Staje się On główną siłą króla, pielgrzyma i każdego zagrożonego człowieka. Sam nie ma już siły ani motywacji, pomysłu na skuteczny kontratak, dlatego Boga prosi o Jego osobistą interwencję: „Wystąp, Panie, przeciw tym, co walczą ze mną, uderz na moich napastników!" (Ps 35, 1).

Lęk przed wrogiem rodzi w psalmiście gniew i złość. To sprawia, że prośby kierowane do Boga są przepełnione złorzeczeniami ${ }^{20}$. Mogą one być dwojakiego rodzaju. Jak zauważa Xavier Perrin ${ }^{21}$, wszelkiego rodzaju przekleństwa mogą być skierowane ku jednemu, konkretnemu wrogowi bądź jakiejś nieprzyjaznej zbiorowości.

Lęk może prowadzić do złorzeczeń trudno zrozumiałych dla współczesnego czytelnika psalmów. Nie są one ściśle związane z tematyką bieżącego artykułu, ale ich analiza pozwala wysunąć kolejny ważny dla niego aspekt. Są one wyrazem sprzeciwu wobec wszelakiego zła.

Lęk przed nieprzyjacielem wojennym czy prześladowcą religijnym jest więc po prostu lękiem przed złem, które napawa trwoga (bo takie określenie jest najbardziej adekwatne do przeżywanego uczucia) przed oskarżycielem. Wszelki przejaw zła spotykany we własnym zachowaniu, myśleniu, w postępowaniu drugiego człowieka napełnia strachem przed działaniem ciemnych i nieznanych sił.

„Zły” w psalmach określany jest jako: bezbożny, kłamca, naśmiewca, złoczyńca, zdzierca, głupiec, podły, niegodziwiec, przestępca, winowajca ${ }^{22}$, nieprzyjaciel (Ps 7, 6; 31, 9), ciemięzca (Ps 3, 2; 13, 5; 27, 2. 12), prześladowca (Ps 7, 2; 31, 16; 142, 7), przeciwnik (Ps 59, 2), oszczerca (Ps 5, 9; 27, 12; 54, 7), nienawistnik (Ps 35, 19; 38, 20; 41, 8; 69, 5; 86, 17), napastnik (Ps 35, 1; 56, 2n). Zaliczany jest też często do grabieżców (Ps 35, 10), szyderców (Ps 102,9$)^{23}$. Ten nieprawy to po prostu rā̂sāa ${ }^{\prime}$, który oznacza człowieka występnego, bezbożnego ${ }^{24}$.

${ }^{19}$ Międzynarodowy komentarz do Pisma Świętego. Komentarz katolicki i ekumeniczny na XXI wiek, red. nauk. wyd. oryg. W. R. Farmer i in., red. nauk. wyd. pol. W. Chrostowski i in., Warszawa 2000, s. 1715.

${ }^{20}$ Por. Ps 5, 11; 20, 9-13 ; 53, 7; 54, 16; 57, 7-10; 58, 12-16; 78, 6; 108, 6-15; 139, 12.

${ }^{21}$ Por. X. Perrin, Obecność złorzeczeń w Psalterzu, „W drodze” 7 (2003), s. 112.

${ }^{22}$ Por. L. Stachowiak, Problematyka zła w Starym i Nowym Testamencie, [w:] Studio lectionem facere, pr. zb. pod red. S. Lacha i J. Szlagi, Lublin 1978, s. 198-199.

${ }^{23}$ Por. J. Schreiner, R. KAmpling, Bliźni-obcy-nieprzyjaciel..., dz. cyt., s. 65-66

${ }^{24}$ J. Schreiner, R. KAMPling, Bliźni-obcy-nieprzyjaciel..., dz. cyt., s. 66, [za:] H. Gunkel, Einleitung in die Psalmen, Göttingen 1933, 196n. 
Analiza psalmów pozwala zauważyć prostotę ówczesnej wizji świata. Jest albo dobry, albo zły. Ten kontrast występuje dosyć często. Psalmista nie bierze pod uwagę życia pośredniego między tymi stanami. Wywołałoby to w nim dodatkowe wewnętrzne frustracje, obawy. Drogi te są sobie zwyczajnie przeciwstawne.

Warszawa

MAEGORZATA LASKOWSKA

\section{Summary}

\section{The psalmist's fear of enemy}

The figure of enemy and the fear of him appears in the Holy Bible a lot of times, especially in psalms, in the context of persecution and hatered against the belivers of Jahwe. The fear considers a pilgrim, but also a king and the whole nation who is affraid of invaders. However the prayers of the scared are answered. God gives courage, helps overcome the fear. 